\title{
Pengaruh Penerapan Budaya Kerja (Corporate Culture) terhadap Kinerja Pegawai pada PT Bank Perkreditan Rakyat Puskopat Palembang
}

\author{
Elizabeth Irene Putri Sianturi' ${ }^{1)}$, Hamid Halin ${ }^{2)}$, Susi Handayani ${ }^{3)}$ \\ 1), 2), 3) Universitas Indo Global Mandiri, Palembang \\ Email: elizabethirene15@gmail.com ${ }^{1)}$,hamidhalin@ugim.ac.id ${ }^{2}$,susi@uigm.ac.id ${ }^{3)}$
}

\begin{abstract}
This study aims to analyze the influence of the application of work culture (corporate culture) on employee performance at PT Bank Perkreditan Rakyat Puskopat Palembang. The processed data is the result of a questionnaire from 32 respondents. The analytical method applied in this research is multiple linear regression analysis. The results of the study prove that work culture $(\mathrm{X})$ has a simultaneous effect on employee performance (Y). This research is expected to provide benefits to PT Bank Perkreditan Rakyat Puskopat Palembang to improve employee performance.
\end{abstract}

Keywords: work culture, employee performance, people's credit bank

\begin{abstract}
Abstrak
Penelitian ini bertujuan untuk menganalisa pengaruh penerapan budaya kerja (corporate culture) terhadap kinerja pegawai pada PT Bank Perkreditan Rakyat Puskopat Palembang. Data yang diolah merupakan hasil kuesioner dari 32 responden. Metode analisis yang diterapkan pada penelitian ini adalah analisis regresi linear berganda. Hasil penelitian membuktikan bahwa budaya kerja (X) berpengaruh secara simultan terhadap kinerja pegawai (Y). Penelitian ini diharapkan dapat memberikan manfaat pada PT Bank Perkreditan Rakyat Puskopat Palembang untuk meningkatkan kinerja pegawainya.
\end{abstract}

Kata Kunci: budaya kerja, kinerja pegawai, bank perkreditan rakyat

\section{Pendahuluan}

\subsection{Latar Belakang}

Saat ini kemampuan sumber daya manusia masih rendah terbukti dalam urutan Human Development Indeks Indonesia, yang berada pada urutan 121 dari 185 negara. Hal ini akan berdampak pada rendahnya daya saing dalam berbagai bidang (Dimyati, 2013). Salah satu faktor yang mempengaruhi kinerja pegawai dalam suatu organisasi atau perusahaan adalah budaya kerja, dimana faktor tersebut sangat erat kaitannya dalam meningkatkan kinerja pegawai, sebab dengan tercapainya budaya kerja yang baik dan ditunjang oleh kerjasama sesama pegawai, maka akan tercapai hasil yang dapat meningkatkan kinerja kerja pegawai (Tika, 2010).

Salah satu upaya untuk mendorong tumbuh dan berkembangnya budaya kerja adalah dengan pembinaan dan pengembangan budaya kerja yang baik. Budaya kerja tersebut meliputi disiplin dan motivasi. Mengembangkan budaya kerja yang ada dalam masyarakat menjadi lebih peka terhadap tuntutan dan lebih sesuai dengan perkembangan kebutuhan dan teknologi. Dalam hal ini, nilai-nilai dasar yang dipandang masyarakat sebagai ciri-ciri kebaikan, hendak direalisasikan dalam penataan birokrasi pemerintahan.

Keadaan ini antara lain berkaitan dengan pisahnya kedudukan dan wewenang antar instansi 
sehingga menyebabkan kurangnya professionalisme dan kurangnya moral. Budaya kerja menurut Mangkunegara, 2017 yang dikutip dari Edgar H. Schein mendefinisikan bahwa budaya kerja adalah seperangkat asumsi atau sistem keyakinan, nilai-nilai dan norma yang dikembangkan dalam organisasi yang dijadikan pedoman tingkah laku bagi anggotaanggotanya untuk mengatasi masalah adaptasi eksternal dan integrasi internal.

\subsection{Fenomena Perusahaan}

Fenomena yang terjadi di PT. Bank Perkreditan Rakyat Puskopat ini adalah hampir setiap karyawan yang bekerja di perusahaan tsb memiliki sifat yang merasa dirinya mempunyai peran dan pengaruh besar terhadap perusahaan tsb dan tidak menjalankan setiap aturan perusahaan yang berlaku. Sifat yang seperti itu berasal dari karyawan yang merupakan salah satu keluarga pemilik saham di perusahaan tsb dan dari karyawan yang mempunyai pinjaman besar di perusahaan tsb. Sehingga direksi tidak bisa mengeluarkan karyawan-karyawan yang tidak memiliki kinerja yang baik karena adanya faktor yang sudah dijelaskan sebelumnya.

\subsection{Rumusan Masalah}

Berdasarkan uraian latar belakang di atas, maka rumusan masalah yang akan dikaji dalam penelitian ini adalah: Bagaimana pengaruh budaya kerja terhadap kinerja karyawan pada PT Bank Perkreditan Rakyat Puskopat Palembang?

\subsection{Tujuan Penelitian}

Adapun tujuan dari penelitian ini adalahUntuk mengetahui pengaruh budaya kerja terhadap kinerja karyawan pada PT Bank Perkreditan Rakyat Puskopat sehingga dengan adanya budaya kerja yang baik dapat meningkatkan kinerja karyawan.

\section{Tinjauan Pustaka}

\subsection{Sumber Daya Manusia}

Manajemen merupakan suatu bagian dari manajemen yang khusus mempelajari hubungan dan peranan manusia dalam organisasi. Menurut Hasibuan (2011:10) berpendapat bahwa manajemen sumber daya manusia adalah ilmu dan seni yang mengatur hubungan dan peranan tenaga kerja agar efektif dan efisien membantu terwujudnya tujuan organisasi, karyawan dan masyarakat. Dari penjelasan tersebut, mengenai sumber daya manusia dapat disimpulkan bahwa sumber daya manusia adalah merupakan asset dan berfungsi sebagai penggerak organisasi dalam mewujudkan keberhasilan suatu organisasi.

\subsection{Budaya Kerja}

Budaya kerja pada sebuah perusahaan terbentuk sejak satuan kerja atau perusahaan tersebut berdiri. Pembentukan budaya kerja terjadi ketika suatu satuan kerja atau perusahaan menghadapi suatu permasalahan yang berkenaan dengan keberlangsungan suatu perusahaan yang menyangkut perubahan-perubahan eksternal maupun internal. (Lijan dkk, 2012). Usman (2013), budaya kerja adalah suatu asumsi penting dari suatu kebiasaan yang dinyatakan naik tertulis maupun tidak tertulis, yang dianut anggotanya dan dijadikan acuan dalam mencapai tujuan organisasi.

Budaya kerja pada umumnya merupakan pernyataan filosofis, dapat difungsikan sebagai tuntutan yang mengikat pada karyawan karena dapat diformulasikan secara formal. Dalam berbagai peraturan dan ketentuan perusahaan. Moeljono, 2012 mengemukakan bahwa budaya kerja pada umumnya merupakan pernyataan filosofis, dapat difungsikan sebagai tuntutan yang 
mengikat pada karyawan karena dapat diformulasikan secara formal.

\subsubsection{Jenis-Jenis Budaya Kerja}

\subsubsection{Budaya Kerja Timbal Balik}

Budaya kerja ini mendukung adanya umpan balik yang jujur di atas semua bentuk komunikasi lainnya. Saat seorang pekerja perlu meningkatkan performa, maka atasan akan langsung mengingatkannya tentang hal tersebut. Sebaliknya, jika manajer tidak produktif atau kurang bertanggung jawab, maka manajemen akan memfasilitasi bentuk komunikasi untuk menemukan solusi terebut.

\subsubsection{Budaya Kerja Transparan}

Hampir sama seperti poin sebelumnya, komunikasi merupakan kunci dari suatu hubungan yang baik dalam perusahaan dan sebuah komunikasi yang baik tentu membutuhkan transparansi. Hal ini bukan berarti setiap orang di perusahaan tahu berapa banyak uang yang dihasilkan orang lain, tetapi transparansi di sini lebih kepada keyakinan bahwa apapun yang dikerjakan tiap orang dalam organisasi sejalan dengan tujuan yang lebih luas. Salah satu perusahaan yang menganut prinsip ini adalah Highfive. Shan, CEO Highfive akan melakukan Q\&A dalam sebuah makan siang dan menjawab pertanyaan-pertanyaan karyawan yang telah dimasukkan ke dalam sebuah kotak.

\subsubsection{Budaya Kerja Berfokus Pada Individu}

Budaya kerja seperti ini menawarkan fleksibilitas kepada setiap orang untuk menyesuaikan gaya kerjanya masing-masing. Salah satu caranya mungkin dengan mengizinkan beberapa karyawan bekerja dari rumah (remote work) jika itu tidak mengganggu produktivitas.

\subsubsection{Budaya Kerja Tanpa Dinding Pembatas}

Lingkungan kerja tanpa adanya dinding pembatas akan menciptakan budaya kerja tim yang lebih baik. Kantor yang membiarkan ruangannya terbuka tanpa bilik akan membuat karyawannya dapat berbicara antara satu sama lain dengan bebas. Lingkungan kerja semacam ini juga biasanya memiliki ruang istirahat bersama yang membuat karyawan semakin membaur dan menghilangkan jarak antar divisi.

\subsubsection{Budaya Kerja Tim}

Budaya kerja tim akan memungkinkan setiap orang untuk bekerja secara individu dengan tetap fokus pada keberhasilan sebagai sebuah tim. Lingkungan semacam ini biasanya akan menentukan tujuan tim dan memungkinkan setiap orang bekerja sama dalam kelompok yang lebih kecil untuk menyelesaikan tugas kelompok.

\subsubsection{Budaya Kerja Menyenangkan Dengan Unsur Lelucon}

Tidak melulu harus serius dalam merencanakan suatu hal atau mengembangkan ide, unsur lelucon ternyata dapat membangkitkan kreatifitas dan semangat seseorang dalam bekerja. Unsur ini juga akan menegaskan kepada tiap karyawan bahwa perusahaan merangkul setiap kreatifitas.

\subsubsection{Indikator Budaya}

Budaya kerja merupakan sejumlah pikiran dasar atau program mental yang dapat dimanfaatkan untuk meningkatkan efektivitas kerja dan kerjasama manusia yang dimiliki oleh suatu golongan masyarakat, serta membagi budaya kerja menjadi dua unsur, yaitu (Sulaeman, 2014): 
1. Sikap terhadap pekerjaan yakni kesuksesan akan kerja dibandingkan dengan kegiatan lain, seperti bersantai, atau semata-mata memperoleh kepuasan dari kesibukan pekerjaannya sendiri, atau merasa terpaksa melakukan sesuatu hanya untuk kelangsungan hidupnya.

2. Perilaku pada waktu bekerja, yaitu seperti rajin, berdedikasi, tanggung jawab, berhatihati, teliti, cermat, kemauan yang kuat untuk mempelajari tugas dan kewajibannya, suka membantu sesama karyawan atau sebaliknya.

\subsubsection{Fungsi dan Manfaat Budaya Kerja}

Fungsi budaya dan manfaat budaya kerja adalah sebagai berikut (Robbins, 2015):

1. Mempunyai boundrary-difining roles, yaitu menciptakan perbedaan antara organisasi yang satu dengan lainnya.

2. Menyampaikan rasa identitas untuk anggota organisasi

3. Budaya memfasilitasi bangkitnya komitmen pasa sesuatu yang lebih besar daripada kepentingan diri individual.

4. Meningkatkan stabilitas sistem sosial. Budaya adalah perekat sosial yang membantu menghimpun organisasi bersama dengan memberikan standar yang cocok atas apa yang dikatakan dan dilakukan pekerja.

5. Budaya melayani sebagai sense-making dan mekanisme kontrol yang membimbing dan membentuk sikap dan perilaku karyawan.

\subsubsection{Karakteristik Budaya Kerja}

Budaya kerja dalam suatu organisasi yang satu dapat berbeda dengan yang ada dalam organisasi yang lain. Namun, budaya kerja menunjukkan cirri-ciri, sifat atau karakteristik budaya organisasi sangat bervariasi. Hal ini menunjukkan beragamnya ciri, sifat dan elemen yang terdapat dalam budaya kerja (Wibowo, 2010:31). Karakteristik kunci dari budaya adalah : budaya dipelajari, norma dan adat istiadat adalah umum di seluruh budaya, budaya kebanyakan bekerja secara tanpa sadar, proses social, elemen budaya diteruskan dari satu generasi ke generasi berikutnya, menyesuaikan adat istiadat dan pola perilaku yang dapat diterima cenderung menjadi berhubungan dengan kebajikan moral dan superioritas, dan seperti kebiasaan lainnya, perilaku budaya adalah nyaman dan dikenal umum.

\subsection{Kinerja Pegawai}

\subsubsection{Pengertian Kinerja Pegawai}

Kinerja berasal dari kata job performance atau actual performance yang berarti prestasi kerja atau prestasi sesungguhnya yang dicapai oleh seseorang. Sangatlah sulit untuk menetapkan suatu definisi kinerja yang dapat memberikan pengertian yang komprehensif. Penggunaan kata kinerja sendiri pun terkadang disamaartikan dengan prestasi kerja, efektivitas kerja, hasil kerja, pencapaian tujuan dan produktifitas kerja. Kinerja pegawai sangatlah perlu, sebab dengan kinerja ini akan diketahui seberapa jauh kemampuan mereka dalam melaksanakan tugas yang dibebankan kepadanya. Untuk itu, diperlukan penentuan kriteria yang jelas dan terukur, serta ditetapkan secara bersama-sama untuk dijadikan sebagai acuan. Hanya beberapa masukan tersebut relevan dengan kinerja disini, antara lain:

1. Melakukan 
2. Memenuhi atau menjalankan sesuatu

3. Melaksanakan suatu tanggung jawab

4. Melakukan sesuatu yang diharapkan oleh seseorang

\subsubsection{Indikator Kinerja Pegawai}

Indikator untuk mengukur kinerja karyawan secara individu ada lima indikator, yaitu:

1. Kualitas. Kualitas kerja diukur dari persepsi karyawan terhadap kualitas pekerjaan yang dihasilkan serta kesempurnaan tugas terhadap keterampilan dan kemampuan karyawan.

2. Kuantitas. Merupakan jumlah yang dihasilkan dinyatakan dalam istilah seperti jumlah unit, jumlah siklus aktivitas yang diselesaikan.

3. Ketepatan waktu. Merupakan tingkat aktivitas diselesaikan pada awal waktu yang dinyatakan, dilihat dari sudut koordinasi dengan hasil output serta memaksimalkan waktu yang tersedia untuk aktivitas lain.

4. Efektivitas. Merupakan tingkat penggunaan sumber daya organisasi (tenaga, uang, teknologi, bahan baku) dimaksimalkan dengan maksud menaikkan hasil dari setiap unit dalam penggunaan sumber daya.

5. Kemandirian. Merupakan tingkat seorang karyawan yang nantinya akan dapat menjalankan fungsi kerjanya Komitmen kerja. Merupakan suatu tingkat dimana karyawan mempunyai komitmen kerja dengan instansi dan tanggung jawab karyawan terhadap kantor.

\subsection{Kerangka Pemikiran}

Kerangka berfikir merupakan model konseptual tentang bagaimana teori berhubungan dengan berbagai faktor yang telah diidentifikasi sebagai masalah yang penting. Dalam penelitian ini untuk memecahkan arah dari pemecahan dan penganalisisan masalah yang dihadapi, maka terlebih dahulu perlu dikemukakan gambaran yang berupa kerangka pemikiran sebagai berikut:

Gambar: 2.1 Kerangka Pemikiran

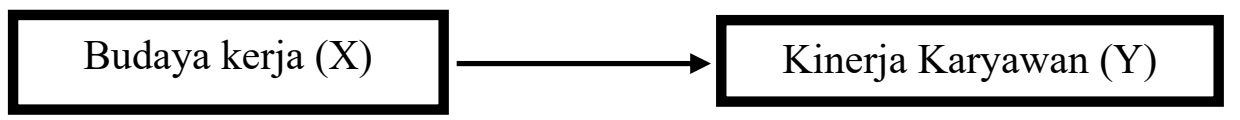

Untuk pengujian hipotesis yang akan diajukan, maka peneliti menentukan variabel variabel yang hendak di ketahui kedudukannya, antara lain:

1. Variabel independent, merupakan variabel yang keberadaannya tidak di pengaruhi oleh variabel lainya. Yang menjadi variabel independent dalam penelitian ini adalah budaya organisasi.

2. Variabel dependent, variabel yang keberadaannya di pengaruhi oleh variabel lainya. Yang termasuk variabel dalam penelitian ini adalah kinerja karyawan. Dari gambar diatas dapat dijelaskan bahwa faktor yang pengaruh kinerja karyawan adalah budaya kerja.

\subsection{Hipotesis}

Menurut Sekaran dan Bougie (dalam Syaiful 2018), hipotesis adalah pernyataan sementara namun dapat diuji untuk memprediksi apa yang ingin ditemukan peneliti dalam data empiris 
peneliti. Hipotesis dinyatakan sebagai jawaban sementara terhadap rumusan masalah, karena jawaban tersebut hanya didasarkan pada teori yang relevan dan hasil penelitian sebelumnya. Berdasarkan uraian-uraian pada latar belakang masalah dengan memperhatikan teori-teori serta pendapat-pendapat yang ada, maka dapat dikemukakan hipotesis dalam penelitian ini sebagai berikut:

- $\quad \mathrm{H}_{\mathrm{o}}=$ Diduga budaya kerja berpengaruh terhadap kinerja karyawan

- $\mathrm{H}_{\mathrm{a}}=$ Diduga budaya kerja tidak berpengaruh terhadap kinerja karyawan

\section{Metode Penelitian}

\subsection{Ruang Lingkup Penelitian}

Agar penelitian ini dapat dilakukan lebih fokus, sempurna dan mendalam maka peneliti hanya memandang permasalahan penelitian yang diangkat hanya berkaitan dengan budaya kerja terhadap kenerja karyawan pada PT. Bank Perkreditan Rakyat Puskopat Palembang.

\subsection{Objek Penelitian}

Di penelitian ini, saya menetili sebuah budaya kerja disebuah perusahaan yang sebagai objeknya. Secara garis besar penjelasan tentang budaya organisasi sudah dijelaskan pada bab sebelumnya. Jenis penelitian yang diambil adalah data subjek dengan menggunakan kuisioner dan wawancara berdasarkan opini dan pengalaman dengan jumlah populasi sebagian besar karyawan pada PT. Bank Perkreditan Rakyat Puskopat Palembang.

\subsection{Waktu dan Tempat Penelitian}

Penelitian ini akan dilaksanakan langsung di perusahaan yang akan diteliti. Waktu penelitian akan dilaksanakan pada saat setelah selesai seminar proposal sekitar 1 semester yang bertempat di Jl. Jend. Sudirman.

\subsection{Batasan Penelitian}

Berdasarkan identifikasi masalah yang dipaparkan sebelumnya, supaya penelitian ini lebih fokus tidak meluas dari pembahasan yang dimaksud maka dalam penelitian ini, penulis membatasi permasalahan yang dikaji pada ruang lingkup tentang Pengaruh Penerapan Budaya Kerja (Corporate Culture) Terhadap Kinerja Karyawan Pada PT. Bank Perkreditan Rakyat Puskopat Palembang.

\subsection{Jenis dan Sumber Data}

\subsubsection{Jenis Data}

Menurut Sanusi (2015:104) Terdapat dua jenis data yang digunakan dalam penelitian ini yaitu sebagai berikut:

a. Data Kualitatif merupakan penelitian yang didasarkan secara fisik kita amati, dicatat, serta diklarifikasi menurut tempat dan waktu yang melatar belakang peristiwa.

b. Data Kuantitatif merupakan penelitian yang didasarkan pada pengumpulan dan analisis data berbentuk angka dengan cara memberi skor.

\subsubsection{Sumber Data}

a. Data Primer adalah data yang diperoleh langsung oleh peneliti melalui observasi atau pengamatan langsung yang diperoleh langsung dari sumbernya, diamati, dan dicatat, 
untuk pertama kalinya melalui wawancara kepada pemilik toko kain batik jumputan.

b. Data Sekunder adalah data pendukung bagi data primer, yang diperoleh dari internet, jurnal, buku, artikel, dan liberal-liberal yang berkaitan dengan pembahasan permasalahan yang ada hubungannya dengan penelitian tersebut.

\subsection{Teknik Pengumpulan Data}

Metode pengumpulan data yang diperlukan dalam penelitian ini ialah melalui kuesioner. Menurut Arikunto (2013) kuesioner atau angket adalah seperangkat pernyataan atau pertanyaan tertulis yang diberikan kepada responden untuk dijawab. Angket ini berupa daftar pernyataan yang dibuat peneliti dan harus dijawab oleh responden. Angket yang akan digunakan disusun menurut skala likert. Skala ini digunakan oleh para peneliti guna mengukur persepsi, sikap ataupun pendapat seseorang atau sekelompok orang tentang fenomena sosial.

\subsection{Populasi dan Sampel}

\subsubsection{Populasi}

Populasi adalah keseluruhan objek penelitian dan memenuhi karakteristik tertentu. Menurut Sekaran dan Bougie (2013) dalam Syaiful (2018), populasi adalah sekelompok orang, kejadian, atau hal-hal menarik dan selanjutnya peneliti ingin menginvestigasi dan membuat opini. Populasi dalam penelitian ini sebanyak 32 orang karyawanPT. Bank Perkreditan Rakyat Puskopat Palembang.

\subsubsection{Sampel}

Sampel menurut (Sugiono, 2014) adalah bagian dari jumlah dan karakteristik yang dimiliki oleh populasi tersebut sampel yang diambil dari populasi tersebut harus betul-betul mewakili (representative). Ukuran sampel merupakan banyaknya sampel yang akan diambil dari suatu populasi. Sampel pada penulisan ini meliputi semua karyawan sebanyak 32 karyawan PT. Bank Perkreditan Rakyat Puskopat Palembang.

\subsection{Teknik Analisis Data}

\subsubsection{Uji Validitas}

Digunakan untuk mengukur sah (valid) atau tidaknya suatu kuesioner. Suatu kuesioner dikatakan valid jika pertanyaan pada kuesioner mampu untuk mengungkap suatu yang akan diukur oleh kuesioner tersebut. Uji validitas dihitung dengan membandingkan nilai $r$ hitung (correlated item-total correlation) dengan nilai $r$ table, jika $r$ hitung $>r$ tabel dan nilai positif maka butir atau pertanyaan tersebut dinyatakan valid (Ghozali, 2013:45).

\subsubsection{Uji Reliabilitas}

Data untuk mengukur suatu kuisioner yang merupakan indikator dari variabel atau konstruk. Suatu kuisioner dikatakan reliable atau handal jika jawaban seseorang terhadap pertanyaan adalah konsisten atau stabil dari waktu ke waktu.

\subsubsection{Analisis Regresi Linear Sederhana}

Tujuan dari teknik analisis Regresi adalah untuk prediksi bagaimana perubahan nilai yang terjadi pada variabel $\mathrm{X}$ dan variabel $\mathrm{Y}$ dimanipulasi (dinaikkan atau diturunkan nilainnya). Penelitian ini menggunakan analisis regresi linier sederhana. Menurut (Sujarweni W, 2014) menjelaskan bahwa regresi liner sederhana merupakan regresi yang memiliki satu variabel dependen dan satu variabel idependen. Bentuk umum persamaan analisis regresi linear 
sederhana sebagai berikut:

Keterangan:

$\mathrm{Y} \quad=$ variabel dependen

a $\quad=$ nilai konstanta (parameter intercept)

$\mathrm{b} \quad=$ koefisien regresi

$\mathrm{x} \quad=$ variabel independen

\subsubsection{Uji Parsial (T test)}

Uji t adalah pengujian koefisien regresi parsial individual yang digunakan untuk mengetahui apakah variabel independen $(\mathrm{X})$ secara individual mempengaruhi variabel dependen $(\mathrm{Y})$. Sujarweni (2015), dasar pengambilan Uji t parsial adalah sebagai berikut:

1. Jika nilai $t_{\text {hitung }}>t_{\text {table }}$ maka variabel bebas berpengaruh terhadap variabel terkait.

2. Jika nilai $t_{\text {hitung }}<\mathrm{t}_{\text {table }}$ maka variabel bebas tidak berpengaruh terhadap variabel terikat.

\subsubsection{Uji Koefisian Korelasi (R)}

Koefisien korelasi adalah nilai yang menunjukan kuat/tidaknya hubungan linier antar dua variabel. Koefisien korelasi biasa dilambangkan dengan huruf $r$ dimana nilai $r$ dapat bervariasi dari -1 sampai +1 . Nilai $r$ yang mendekati -1 atau +1 menunjukan hubungan yang kuat antara dua variabel tersebut dan nilai r yang mendekati 0 mengindikasikan lemahnya hubungan antara dua variabel tersebut. Sedangkan tanda + (positif) dan - (negatif) memberikan informasi mengenai arah hubungan antara dua variabel tersebut. Jika bernilai + (positif) maka kedua variabel tersebut memiliki hubungan yang searah.

Tabel 3.1. Pedomen Interpretasi Koefisien Korelasi

\begin{tabular}{|c|c|}
\hline Tabel Koefisien & Tingkat Hubungan \\
\hline $0,00-0,199$ & Sangat Rendah \\
\hline $0,20-0,399$ & Rendah \\
\hline $0,40-0,599$ & Sedang \\
\hline $0,60-0,799$ & Kuat \\
\hline $0,80-1,000$ & Sangat Kuat \\
\hline
\end{tabular}

Sumber: Sugiyono (2018)

\subsubsection{Uji Koefisian Determinasi $\left(R^{2}\right)$}

Menurut Imam Ghozali, koefisien determinasi pada intinya mengukur seberapa jauh kemampuan sebuah model dalam menerangkan variasi variabel dependen. Nilai koefisien determinasi adalah antara nol dan satu. Nilai $\mathrm{R}^{2}$ yang kecil berarti variasi variabel dependen yang sangat terbatas, dan nilai yang mendekati 1 (satu) berarti variabel-variabel independen sudah dapat memberi semua informasi yang dibutuhkan untuk memprediksi variabel dependen.

\subsubsection{Definisi Operasional dan Pengukuran Variabel}


a. Definisi operasinal adalah variabel penelitian dimaksudkan untuk memahami arti setiap variabel penelitian sebelum dilaukan analisis, instrumen, serta sumber pengukuran berasal dari nama (Sujarweni, 2015:77).

b. Variabel penelitian merupakan sesuatu hal yang berbentuk apa saja yang di tetapkan oleh penliti untuk di pelajari sehingga di peroleh informasi tentang hal terebut, dan kemuadia di tarik ke simpulannya (Sujarweni, 2015:75).

Tabel 3.2. Skala Pengukuran Variabel

\begin{tabular}{|c|c|c|}
\hline No. & Kriteria & Skor \\
\hline 1. & Sangat Setuju (SS) & 5 \\
\hline 2. & Setuju (S) & 4 \\
\hline 3. & Kurang Setuju (KS) & 3 \\
\hline 4. & Tidak Setuju (TS) & 2 \\
\hline 5. & Sangat Tidak Setuju (STS) & 1 \\
\hline
\end{tabular}

Sumber: Sugiyono (2016)

Sesuai dengan identifikasi penelitian, maka definisi operasional dari masing-masing variable adalah sebagai berikut:

Tabel 3.3 Definisi Variabel

\begin{tabular}{|c|c|c|c|c|}
\hline Variabel & Definisi Variabel & Indikator & Nilai & Skala \\
\hline $\begin{array}{l}\text { Budaya Kerja } \\
(\mathrm{X})\end{array}$ & $\begin{array}{l}\text { Budaya kerja merupakan } \\
\text { suatu komitmen organisasi } \\
\text { yang luas dalam upaya } \\
\text { membangun sumber daya } \\
\text { manusia, proses kerja dan } \\
\text { hasil kerja yang lebih baik. } \\
\text { (Osborn, 2010) berpendapat } \\
\text { bahwa budaya kerja adalah } \\
\text { seperangkat } \\
\text { perasaan dan } \\
\text { psikologis kerangka } \\
\text { terinternalisasi } \\
\text { mendalam dan dimiliki } \\
\text { bersama anggota organisasi. }\end{array}$ & $\begin{array}{l}\text { - Sikap terhadap } \\
\text { pekerjaan } \\
\text { - Perilaku pada waktu } \\
\text { bekerja }\end{array}$ & $1-2$ & $\begin{array}{l}\text { Skala } \\
\text { Likert }\end{array}$ \\
\hline $\begin{array}{l}\text { Kinerja } \\
\text { Karyawan (Y) }\end{array}$ & $\begin{array}{lr}\text { Kinerja } & \text { karyawan } \\
\text { didefinisikan } & \text { sebagai } \\
\text { kemampuan karyawan dalam } \\
\text { melakukan sesuatu keahlian }\end{array}$ & $\begin{array}{ll}\text { - } & \text { Kualitas kerja. } \\
\text { - } & \text { Kuantitas kerja. } \\
\text { - } & \text { Ketepatan waktu }\end{array}$ & $1-5$ & $\begin{array}{l}\text { Skala } \\
\text { Likert }\end{array}$ \\
\hline
\end{tabular}




\section{Hasil dan Diskusi}

Berdasarkan kuesioner yang dibagikan kepada responden sebanyak 32 orang karyawan PT Bank Perkreditan Rakyat Puskopat. Kemudian hasil kuesioner dianalisis denganmenggunakan SPSS v.24 for windows untuk mendapatkan hasil penelitian sebagai berikut:

\subsection{Pembahasan}

\subsubsection{Karakteristik Responden}

Deskripsi profil responden menjelaskan tentang identitas dari responden yang di jadikan sampel. Dimana perlu di tambahkan bahwa penyebaran kuesioner kepada responden yang menunjukan bahwa semua responden telah mengembalikan kuesioner dan telah di isi secara lengkap dan benar. pada penelitian ini, penulis membagi responden dalam beberapa karakteristik berdasarkan usia, jenis kelamin, pendidikan terakhir dan lama masa kerja.

1. Karakteristik responden berdasarkan umur

Informasi dalam Tabel 4.1 menunjukkan tingkat kontribusi responden berdasarkan umur 17- 21 tahun sebanyak 8 responden dengan persentase 25,8\% umur 22-26 tahun sebanyak 15 responden dengan persentase 48,4\%, umur 27-31 tahun sebanyak 5 responden dengan persentase $16,1 \%$, umur $32-36$ tahun sebanyak 3 responden dengan persentase $9,7 \%$. Hal ini dapat dilihat pada tabel 4.1 dibawah ini:

Tabel 4.1 Umur Responden

\begin{tabular}{|l|l|r|r|r|r|}
\hline \multicolumn{2}{|c|}{} & \multicolumn{1}{|c|}{ Frequency } & \multicolumn{1}{|c|}{ Percent } & \multicolumn{1}{|c|}{$\begin{array}{c}\text { Valid } \\
\text { Percent }\end{array}$} & $\begin{array}{c}\text { Cumulative } \\
\text { Percent }\end{array}$ \\
\hline \multirow{5}{*}{ Valid } & $17-21$ tahun & 8 & 25.8 & 25.8 & 25.8 \\
\cline { 2 - 6 } & $22-26$ tahun & 15 & 48.4 & 48.4 & 94.2 \\
\cline { 2 - 6 } & $27-31$ tahun & 5 & 16.1 & 16.1 & 100.0 \\
\cline { 2 - 6 } & $32-36$ tahun & 3 & 9.7 & 9.7 & \\
\cline { 2 - 6 } & Total & 31 & 100.0 & 100.0 & \\
\hline
\end{tabular}

2. Karakteristik responden berdasarkan jenis kelamin dapat di lihat pada tabel berikut ini:

Tabel 4.2 Jenis Kelamin Responden

\begin{tabular}{|r|l|r|r|r|r|}
\hline \multicolumn{2}{|c|}{} & \multicolumn{1}{|c|}{ Frequency } & \multicolumn{1}{c|}{ Percent } & \multicolumn{1}{c|}{$\begin{array}{c}\text { Valid } \\
\text { Percent }\end{array}$} & $\begin{array}{c}\text { Cumulative } \\
\text { Percent }\end{array}$ \\
\hline \multirow{2}{*}{ Valid } & Laki-laki & 15 & 48.4 & 48.4 & 48.4 \\
\cline { 2 - 6 } & Perempuan & 16 & 51.6 & 51.6 & 100.0 \\
\hline
\end{tabular}




\section{Total}

\section{1}

100.0

100.0

Informasi pada tabel 4.2 menunjukan bahwa responden dalam penelitian ini berjenis kelamin laki-laki sebanyak 15 responden dengan persentase 48,4\% sedangkan responden berjenis kelamin perempuan sebanyak 16 responden dengan persentase $51,6 \%$.

3. Karateristik responden berdasarkan pendidikan terakhir dapat dilihat pada tabel berikut ini:

Tabel 4.3 Pendidikan Terakhir Responden

\begin{tabular}{|l|l|r|r|r|r|}
\hline \multicolumn{2}{|c|}{} & \multicolumn{1}{|c|}{ Frequency } & \multicolumn{1}{c|}{ Percent } & \multicolumn{1}{c|}{$\begin{array}{c}\text { Valid } \\
\text { Percent }\end{array}$} & $\begin{array}{c}\text { Cumulative } \\
\text { Percent }\end{array}$ \\
\hline \multirow{5}{*}{ Valid } & SMP & 4 & 12.9 & 12.9 & 12.9 \\
\cline { 2 - 6 } & SMA/SMK & 20 & 64.5 & 64.5 & 77.4 \\
\cline { 2 - 6 } & S1 & 5 & 16.1 & 16.1 & 93.5 \\
\cline { 2 - 6 } & Lainnya & 2 & 6.5 & 6.5 & 100.0 \\
\cline { 2 - 6 } & Total & 31 & 100.0 & 100.0 & \\
\hline
\end{tabular}

Informasi dalam tabel 4.3 menunjukan bahwa pendidikan terakhir respon dalam penelitian ini SMP sebanyak 4 responden dengan pesentase 12,9\%, SMA/SMK sebanyak 20 responden dengan persentase $64,5 \%$, S1 sebanyak 5 responden dengan persentase $16,2 \%$, dan lainnya sebanyak 2 responden dengan persentase $6,5 \%$.

\subsection{Pengujian Validitas dan Reliabilitas}

\subsubsection{Uji Validitas}

Digunakan untuk mengukur sah (valid) atau tidaknya suatu kuesioner. Suatu kuesioner dikatakan valid jika pertanyaan pada kuesioner mampu untuk mengungkap suatu yang akan diukur oleh kuesioner tersebut. Uji validitas dihitung dengan membandingkan nilai $r_{\text {hitung }}$ (correlated item-total correlation) dengan nilai $r_{\text {tabel. }}$ jika $r_{\text {hitung }}>r_{\text {tabel }}$ dan nilai positif maka butir atau pertanyaan tersebut dinyatakan valid (Ghozali, 2013:45).

Tabel 4.4 Hasil Uji Validitas Variabel Budaya Kerja (X)

\begin{tabular}{|c|c|c|c|}
\hline Item & $\mathbf{R}_{\text {Hitung }}$ & $\mathbf{R}_{\text {Tabel }}$ & Keterangan \\
\hline Budaya Kerja 1 & 0,417 & 0,300 & Valid \\
\hline Budaya Kerja 2 & 0,331 & 0,300 & Valid \\
\hline Budaya Kerja 3 & 0,417 & 0,300 & Valid \\
\hline Budaya Kerja 4 & 0,331 & 0,300 & Valid \\
\hline
\end{tabular}




\begin{tabular}{|c|c|c|c|}
\hline Budaya Kerja 5 & 0,331 & 0,300 & Valid \\
\hline Budaya Kerja 6 & 0,417 & 0,300 & Valid \\
\hline
\end{tabular}

Tabel 4.5 Hasil Uji Validitas Variabel Kinerja (Y)

\begin{tabular}{|c|c|c|c|}
\hline Item & $\mathbf{R}_{\text {Hitung }}$ & $\mathbf{R}_{\text {Tabel }}$ & Keterangan \\
\hline Kinerja 1 & 0,961 & 0,300 & Valid \\
\hline Kinerja 2 & 0,959 & 0,300 & Valid \\
\hline Kinerja 3 & 0,727 & 0,300 & Valid \\
\hline Kinerja 4 & 0,959 & 0,300 & Valid \\
\hline Kinerja 5 & 0,660 & 0,300 & Valid \\
\hline Kinerja 6 & 0,961 & 0,300 & \\
\hline
\end{tabular}

\subsubsection{Uji Reliabilitas}

Data untuk mengukur suatu kuisioner yang merupakan indikator dari variabel atau konstruk. Suatu kuisioner dikatakan reliable atau handal jika jawaban seseorang terhadap pertanyaan adalah konsisten atau stabil dari waktu ke waktu. Kehandalan yang menyangkut kekonsistenan jawaban jika diujikan berulang pada sampel yang berbeda. SPSS memberikan fasilitas untuk mengukur reliabilitas dengan uji reliableCronbach Alpha (a) suatu konstruk atau reliable dikatakan reliable jika memberikan nilai Cronbach Alpha >0,60 (Ghozali:2013).

Tabel 4.6 Uji Reliabilitas

\begin{tabular}{|c|c|c|c|}
\hline Variabel & Cronchbach's Alpha & Ketentuan $R_{\text {tabel }}$ & Hasil \\
\hline $\mathrm{X}$ & 0.869 & 0.6 & Reliabel \\
\hline $\mathrm{Y}$ & 0.811 & 0.6 & Reliabel \\
\hline
\end{tabular}

Hasil uji reliabilitas tersebut menunjukan semua variabel mempunyai koefisien alpha yang cukup besar yaitu diatas 0.6 sehingga dapat dikatakan semua konsep pengukur masing-masing variabel dari kuesioner reliabilitas sehingga untuk selanjutnya item- item pada masing masing konsep variabel tersebut layak digunakan sebagai alat ukur.

\subsubsection{Analisis Variabel}

\subsubsection{Uji Normalitas}

Uji Normalitas bertujuan untuk menguji apakah dalam model regresi, variabel pengganggu atau residual memiliki distribusi normal. Seperti diketahui bahwa uji t mengasumsikan bahwa nilai 
residual mengikuti distribusi normal. Kalau asumsi ini dilanggar maka uji statistik menjadi tidak valid (Ghozali, 2013).

- Histogram dimana berupa tampilan bentuk grafis untuk menunjukan distribusi data secara visual atau seberapa sering suatu nilai yang berbeda itu sering terjadi dalam suatu kumpulan data.

- Scatter Plot dimana sebuah grafik yang bisa digunakan untuk melihat suatu pola hubungan antara dua variabel, agar bisa menggunakan scatter plot maka skala yang digunakan haruslah skala interval dan rasio.

Gambar 4.1 Histogram Uji Normalitas Kepuasan Konsumen

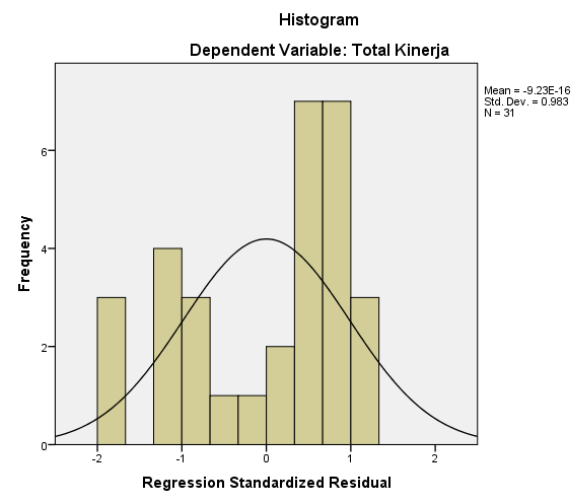

\subsection{Pengujian Hipotesis}

\subsubsection{Uji $T$}

Untuk menguji kebenaran hipotesis yang digunakan dalam penelitian ini pengujian dilakukan menggunakan uji t. Uji t pada dasarnya menunjukkan seberapa jauh pengaruh satu variabel independen secara individual dalam menerangkan variasi variabel dependen. Pengambilan keputusan ini dilakukan berdasarkan perbandingan nilai signifikan yang telah ditetapkan, yaitu sebesar 5\% $(\mathrm{a}=0,05)$. Jika signifikan terhitung lebih besar dari a maka Ho diterima artinya variabel tersebut tidak berpengaruh terhadap variabel dependen. Sedangkan jika signifikan lebih kecil dari a maka Ho ditolak yang artinya variabel independen berpengaruh terhadap dependen.

Tabel 4.7 Menguji Signifikan Variabel Budaya Kerja (X)

\section{Coefficients $^{\mathrm{a}}$}

\begin{tabular}{|c|c|c|c|c|c|c|}
\hline \multirow{2}{*}{\multicolumn{2}{|c|}{ Model }} & \multicolumn{2}{|c|}{$\begin{array}{l}\text { Unstandardized } \\
\text { Coefficients }\end{array}$} & \multirow{2}{*}{$\begin{array}{l}\text { Standardized } \\
\text { Coefficients } \\
\text { Beta }\end{array}$} & \multirow[b]{2}{*}{$\mathrm{T}$} & \multirow[b]{2}{*}{ Sig. } \\
\hline & & B & Std. Error & & & \\
\hline \multirow[t]{2}{*}{1} & (Constant) & 40.565 & 7.344 & & 5.524 & .000 \\
\hline & Total Buday & .461 & .263 & .310 & 1.754 & .000 \\
\hline
\end{tabular}

a. Dependent Variable: Total Kinerja 
Berdasarkan data tabel 4.8 diperolehpada tingkat sig sebesar 0,000 .

Kriteria diterimanya hipotesis:

- Jika sig >0,05 maka $\mathrm{H}_{\mathrm{o}}$ diterima dan $\mathrm{H}_{\mathrm{a}}$ ditolak.

- $\quad$ Taraf nyata $=5 \%$ derajat kebebasan $(\mathrm{df})=\mathrm{n}-2=31-2=29$

Dari hasil perhitungan diatas diketahui bahwa nilaisig $<0,000(0,000<0,05)$ hal ini berarti $\mathrm{H}_{\mathrm{o}}$ diterima dan $\mathrm{H}_{\mathrm{a}}$ ditolak, sehingga dapat disimpulkan bahwa budaya kerjaberpengaruh secara signifikan terhadap kinerja karyawan.

\subsection{Analisis Regresi Linear Sederhana}

Tabel 4.8 Hasil Uji Linier Sederhana

\section{Coefficients $^{\mathrm{a}}$}

\begin{tabular}{|c|c|c|c|c|c|c|}
\hline \multirow{2}{*}{\multicolumn{2}{|c|}{ Model }} & \multicolumn{2}{|c|}{$\begin{array}{l}\text { Unstandardized } \\
\text { Coefficients }\end{array}$} & \multirow{2}{*}{$\begin{array}{l}\text { Standardized } \\
\text { Coefficients } \\
\text { Beta }\end{array}$} & \multirow[b]{2}{*}{$\mathrm{T}$} & \multirow[b]{2}{*}{ Sig. } \\
\hline & & $\mathrm{B}$ & Std. Error & & & \\
\hline \multirow[t]{2}{*}{1} & (Constant) & 40.565 & 7.344 & & 5.524 & .000 \\
\hline & Total Budaya Kerja & .461 & .263 & .310 & 1.754 & .000 \\
\hline
\end{tabular}

a. Dependent Variable: Total Kinerja

Berdasarkan nilai koefisien diatas, dapat disusun persamaan regresi sebagai berikut:

$\mathrm{Y}=\mathrm{a}+\mathrm{b} . \mathrm{X}+\mathrm{e}$

$\mathrm{Y}=40,565+0,461 . \mathrm{X}+7,344$

Berdasarkan tabel diperoleh persamaan regresi linier sederhana variabel Budaya Kerja (X) terhadap Kinerja Karyawan (Y) yaitu :

a. Konstanta (a) sebesar 40,565 menyatakan bahwa jika tidak ada skor variabel budaya kerja $(X=0)$, maka skor variabel kinerja sebesar 40,565.

b. Koefisien regresi variabel budaya kerja (X) mempunyai arah koefisien regresi positif dengan variabel kinerja karyawan yaitu $b=0,461$ artinya: Jika variabel budaya kerja mengalami peningkatan sebesar 1 maka variabel kinerja akan mengalami kenaikan sebesar $(0,461)$.

c. Variabel Penggannggu sebesar 7,344 artinya seluruh variabel yang dihitung dalam uji SPSS memiliki tingkat variabel pengganggu sebesar 7,344.

\subsection{Koefisien Korelasi $(R)$ dan Determinasi $\left(R^{2}\right)$}

\subsubsection{Koefisien Korelasi $(R)$}


Tabel 4.9 Koefisien Korelasi (R)

\begin{tabular}{ll|l|l|l}
\multicolumn{9}{c}{} & \multicolumn{3}{c}{ Model Summary $^{\mathbf{b}}$} & \multicolumn{2}{c}{} \\
Model & R & R Square & Adjusted R Square & $\begin{array}{l}\text { Std. Error of the } \\
\text { Estimate }\end{array}$ \\
\hline 1 & $.310^{\mathrm{a}}$ & .096 & .065 & 2.474 \\
\hline
\end{tabular}

a. Predictors: (Constant), Total Budaya Kerja

b. Dependent Variable: Total Kinerja

Dari tabel diketahui bahwa responden sebanyak 31 dihasilkan nilai korelasi sebesar 0,310 untuk melakukan interprestasi kekuatan hubungan antara dua variabel dilakukan dengan melihat angka koefisien korelasi dari hasil perhitungan dengan menggunakan interprestasi nilai $\mathrm{r}$ sebagai berikut (Sugiono, 2014).

4.5.2 Koefisien Determinasi $\left(R^{2}\right)$

Tabel 4.11 Koefisien Determinasi $\left(\mathrm{R}^{2}\right)$

\begin{tabular}{ll|l|l|l}
\multicolumn{9}{c}{ Model Summary } \\
Model & $R$ & R Square & Adjusted R Square & $\begin{array}{l}\text { Std. Error of the } \\
\text { Estimate }\end{array}$ \\
\hline 1 & $.310^{a}$ & .096 & .065 & 2.474 \\
\hline
\end{tabular}

a. Predictors: (Constant), Total Budaya Kerja

\section{b. Dependent Variable: Total Kinerja}

Berdasarkan dari tabel 4.12 diatas diperoleh nilai R Square sebesar 0,096 atau sama dengan 9,6\%. Angka tersebut dapat disimpulkan bahwa ada pengaruh variabel budaya kerja terhadap kinerja karyawan sebesar 9,6\%, sedangkan $90,4 \%$ dipengaruhi oleh varibel independent lainnya di luar penelitian ini.

\subsection{Pembahasan Penelitian}

Setelah melalui berbagai macam pengujian dan analisis data, maka peneliti mencoba memberikan paparan pembahasan dengan menghubungkan antara teori-teori, penelitianpenelitian terdahulu dengan hasil penelitian yang dilakukan agar dapat memberikan suatu gambaran mengenai pembahasan ilmiah suatu penelitian. Berdasarkan hasil uji t dari hasil perhitungan diatas diketahui bahwa nilaisig $<0,000(0,000<0,05)$ hal ini berarti $\mathrm{H}_{0}$ diterima dan $\mathrm{H}_{\mathrm{a}}$ ditolak, sehingga dapat disimpulkan bahwa budaya kerjaberpengaruh secara signifikan terhadap kinerja karyawan. Hasil penelitian ini membuktikan bahwa secara simultan Budaya Kerja (X) berpengaruh terhadap Kinerja Karyawan (Y) kepada pegawai pada PT Bank Perkreditan Rakyat Hasil penelitian ini didukung oleh penelitian terdahulu Eddy Soegiarto 
(2011), Firdaus (2017), dan Desi Rosiana (2010).

\section{Kesimpulan dan Saran}

\subsection{Kesimpulan}

Setelah melalui berbagai macam pengujian dan analisis data, maka peneliti mencoba memberikan paparan pembahasan dengan menghubungkan antara teori-teori, penelitianpenelitian terdahulu dengan hasil penelitian yang dilakukan agar dapat memberikan suatu gambaran mengenai pembahasan ilmiah suatu penelitian, maka dapat dibuat kesimpulan sebagai berikut:

1. Bedasarkan hasil uji t diperoleh variabel Budaya Kerja (X) mempunyai pengaruh signifikan terhadap Kinerja Pegawai pada PT Bank Perkreditan Rakyat Puskopat. Terlihat sig $0,000<0,05$, sehingga dapat disimpulkan ada pengaruh signifikan budaya kerja terhadap Kinerja Pegawai pada PT Bank Perkreditan Rakyat Puskopat.

2. Berdasarkan hasil uji koefisien korelasi (R) diperoleh nilai sebesar 0,310 hal ini menunjukan bahwa hubungan antara variabel Budaya Kerja (X) mempunyai hubungan yang lemah terhadap variabel Kinerja Pegawai (Y) dengan persentase sebesar 31\%terhadap terhadap Kinerja Pegawai pada PT Bank Perkreditan Rakyat Puskopat.

Dari hasil penelitian koefisien determinasi $\left(\mathrm{R}^{2}\right)$ sebesar 0, 096 atau 9,6\% hal ini menunjukan bahwa lemahnya kontribusi variabel Budaya Kerja (X) dapat menjelaskan Kinerja Pegawai (Y) terhadap Kinerja Pegawai pada PT Bank Perkreditan Rakyat Puskopatsebesar 9,6\%, sisanya sebesar $90,4 \%$

\subsection{Saran}

Setelah melakukan penelitian dan pembahasan, maka penulis akan memberikan saran perbaikan yang berkaitan dengan penelitian yang dilakukan:

\subsubsection{Saran bagi Perusahaan}

1. Pihak PT Bank Perkreditan Rakyat Puskopat harus lebih memperhatikan keinginan dan kenyamanan pegawainya saat ini, supaya dapat bekerja secara maksimal untuk kemajuan perusahaan.

2. Membuat apresiasi pada pegawai,karena persaingan antar pegawai akan membuat pekerjaan para pegawai tidak maksimal, sehingga akan mengakibatkan kerugian kepada perusahaan itu sendiri.

\subsubsection{Saran bagi Peneliti Selanjutnya}

1. Penelitian selanjutnya dapat menambahkan variabel lain sebagai variabel independen baik berasal dari faktor eksternal maupun internal, guna mengetahui variabel-variabel yang dapat memperkuat atau memperlemah variabel dependen.

2. Hasil penelitian ini diharapkan dapat dijadikan penelitian sebelumnya dan juga bagi peneliti selanjutnya, disarankan agar lebih mengembangan variabel-variabel lain guna memberikan kontribusi yang lebih baik.

\section{Referensi}

Budaya dan Perilaku Organisasi (Rois Arifin, S.E., M.M)

Hasibuan (2011:10), Hersey dan Blanchard (1993) dalam Lijan (2012) 
https://blog.ruangguru.com/7-budaya-kerja-yang-harus-dimiliki-perusahaan-agar-lebihsukses , 2 Juli

http://belajarilmukomputerdaninternet.blogspot.com/2013/10/pengertian-kinerjakaryawan.html, Oktober 2013

https://repository.widyatama.ac.id/xmlui/bitstream/handle/123456789/6788/Bab\%202.pdf

https://repository.widyatama.ac.id/xmlui/bitstream/handle/123456789/6788/Bab\%202.pdf),

https://www.kajianpustaka.com/2014/01/pengertian-indikator-faktor-mempengaruhikinerja.html, 12 Januari 2014

Manajemen Sumber Daya manusia (Prof. Dr. Lijan Poltak Sinambela)

Manajemen Sumber Daya manusia, Kinerja Karyawan, (Rivai dan Basri, 2005) (Prof. Dr. Lijan Poltak Sinambela)

Manajemen Sumber Daya manusia, Pengertian Manajemen Sumber Daya Manusia (Simamora, 2001), (Prof. Dr. Lijan Poltak Sinambela)

Manajemen Sumber Daya Manusia (DR.Drs. H. Yani, S.H., M.M)

Nanda Novziransyah, 2017, Pengaruh Budaya Organisasi Terhadap Kinerja .Karyawan

Perilaku Dalam Organisasi (Prof. Dr. Wibowo, S.E., M.Phil)

(Prawirosentono, 1999 dalam Lijan, 2012)

Metodologi Penelitian Bisnis (Sekaran dan Bougie,2013), (Syaiful Bahri, S.E., M.SA., Akt.)

Metodologi Penilitian Bisnis, Definisi Operasional dan Variabel (Sujarweni, 2015:77), (Syaiful Bahri, S.E., M.SA., Akt.)

Metodologi Penilitian Bisnis, Metode Pengumpulan Data (Sanusi, 2017:67), (Syaiful Bahri, S.E., M.SA., Akt.)

Budaya dan Perilaku Organisasi, Pengertian dan Manfaat Budaya (Schiffman dan Kanuk, 2000:322), (Rois Arifin, S.E., M.M, April 2017) 